\title{
The Challenges/Barriers Preventing the South African Youth in Becoming Entrepreneurs: South
} African Overview

\author{
Thobile N Radebe \\ University of Zululand, South Africa \\ radebethobileh@gmail.com
}

\begin{abstract}
Youth entrepreneurship is commonly measured as a significant determinant of poverty reduction, economic development and job creation but the participation of the youth in entrepreneurship is worrisome. Against this background, this study aims to evaluate the challenges that are preventing the youth in starting their own businesses. A qualitative research approach was adopted to enable the use of secondary data literature. The research methodology was undertaken by systematically reviewing and contextualizing the literature regarding the challenges preventing the youth from participating in entrepreneurship activities. The data was analyzed using thematic content analysis. The results showed that the lack of education, society's attitude towards youth entrepreneurship, lack of access to finance and a poor entrepreneurship culture are the barriers that prevent youth from engaging in entrepreneurial activities. A policy implication arising from these findings is that there is a need for entrepreneurship education, better support from society and the provision in terms of the easy access to finance.
\end{abstract}

Keywords: Youth, Entrepreneurship, challenges

\section{Introduction}

South Africa has made a great effort in encouraging entrepreneurial activities, especially when it comes to youth development and involvement. In an environment where jobs are scarce and where unemployment is high, there is an urgent and important need for nurturing entrepreneurship, especially among the youth, particularly in township areas (Nafukho \& Muyia, 2010). In 1994, Former President, Nelson Mandela articulated that the youth are a treasured possession of any nation's quest to develop (Gordon-Davis \& Cumberlege, 2007). Subsequently, the South African government created youth initiatives such as Junior Achievement South Africa (JASA) and National Youth Development Agency (NYDA) to promote the development of youth entrepreneurship and also to help in fighting the challenges that prevent the youth from partaking in entrepreneurship activities or ventures. However, regardless of the support, the rate at which the youth is participating in entrepreneurship activities is worrisome, considering that youth unemployment currently stands at 55.2\% between the ages of 15-34 (Statistics South Africa, 2019). Therefore this study seeks to examine the challenges that prevent the youth from participating in entrepreneurship activities. Additionally, this study seeks to understand why the youth are not participating in entrepreneurship activities, since entrepreneurship has been touted as key in fighting the high unemployment rate in South Africa.

\section{Literature Review}

Entrepreneurship plays an important role in uplifting the economic growth in any country. Nafukho \& Muyia (2010) contend that entrepreneurship, from a global perspective, has been seen as an approach to assist in ensuring the economic participation of young people. Fatoki and Garwe (2010) argue that entrepreneurship is the best method of fighting unemployment \& poverty. Several institutions meant to support youth involvement in entrepreneurship have been created in South Africa and in other countries such as Nigeria. Nonetheless, poverty mitigation, unemployment reduction, and formation of a favourable youth business environment to partake fruitfully and effectively in the economy of the country remain an obstacle in the country (NYDA, 2011). Musengi-Ajulu (2010) agrees that even though there are programmes that are being established which have resulted in many economic opportunities being established for the youth; it seems that they have not made a major impact in reducing the high unemployment rate that is currently affecting the youth. James (2012) argues that nurturing young entrepreneurs could provide an important solution to the country's unemployment dilemma. Entrepreneurship has been seen as vital for job creation, economic development and poverty mitigation (Chiloane-Tsoka \& Mmako, 2014). Nafukho and Muyia (2010) asserted that there is a strong need for entrepreneurship education and training in schools. 
Government Support Initiatives in Promoting Youth Entrepreneurship: The government has recognized the importance of youth entrepreneurship and thus has invested heavily in programs aimed at ensuring entrepreneurial youth development. There are several government programs and private agencies that support and ought to ensure the growth of youth entrepreneurs. For example, in Malaysia, the government plays an active role in supporting and encouraging entrepreneurs by establishing institutions, technology parks, and incubators to encourage young entrepreneurs. Some key institutions or agencies are Technology Malaysia Park (TPM), Malaysian Technology Development Corporation (MTDC), Small Medium Enterprise Corporation (SME Corp), and the Malaysian Global Innovation and Creativity Centre (MaGIC) (Khin and Kee, 2017). In addition, the development of a range of financial institutions enables funds to be utilized effectively and resourcefully ensure continuous investments. In 2011, the Malaysian government established a programme called, '1Malaysia Young Entrepreneurs Challenge' (1MYEC). This programme aims to implant a spirit of entrepreneurship among university students and inspire them to partake in entrepreneurship programmes (MITI, 2011).

Despite the reported efforts of the Malaysian government to promote entrepreneurship, there is still a need to identify whether those efforts meet the need of promising entrepreneurs and what kind of support is still needed. Yet, Africa still has more to catch-up. From a South Africa perspective, the most prominent initiative aimed at supporting young entrepreneurs is known as the National Youth Development Agency (NYDA), whereas, Kenya's quest to ensure entrepreneurship development involved the introduction of entrepreneurship education into the curriculum of all country's technical training institutions. The government of Kenyan government has developed various programs such as the Youth and Women Enterprise Development Fund which aims at assisting in the formation of entrepreneurial projects (Sagwe, Gicharu \& Mahea, 2011). The Youth Enterprise Development Fund has been developed by various private financial intermediaries in partnership with the Ministry of State for Youth Affairs; this fund has been precisely made to improve the youth and to ensure that the youth has the resources to ensure selfemployment via entrepreneurship initiatives (Moraa New Hope Foundation, 2015). The authors further emphasized that the funds can be accessed by the youth either in groups or individually.

In most cases, collateral that is needed to secure money loaned out has been made reasonable and inexpensive in such a way that it can be guaranteed by parents, group guarantee, community leaders or even relatives. With these regulations being improved, the Moraa New Hope Foundation (2015) believes that young people in the country will be able to put an effort towards their life goals that were seemingly delayed by the tough regulation which was hindering them from accessing credit services (Kimando, Njogu \& Kihoro, 2012). Similarly, it was found that in South Africa, none of the municipalities, provincial departments and national agencies had concrete frameworks on small business expansion to monitor their activities (Mazwai, 2012). Moreover, Mazwai (2012) reasoned that local frameworks in developing economy were disadvantageous when it came to empowering communities, and the leadership that was given by the state was not strong. The Nigerian government has put more effort in maintaining order and law and developing an enabling environment where business ventures can succeed. The government encouraged the culture of entrepreneurship by providing opportunities such as business competitions and grants for enterprises. Specific efforts to develop innovation and enterprise have been made in Nigeria.

For instance, there are entrepreneurial oriented institutions that have been developed such as the Youth Enterprise with Innovation in Nigeria (You Win) program (Egwu, 2014). Other opportunities in Nigeria for the development of enterprise include; organizing workshops and seminars at both international and local levels to inspire the creation, registration and cooperation of micro, small and medium business relations. There are also professional relations that were formed with the purpose of stimulating the advancement of industrial organization and businesses through franchising, linkages and co-operation of entrepreneurship activities. For instances, such associations are the Abuja Enterprises Agency (AED), Acadia Centre for Small Business and Entrepreneurship (ACSBE), International Council of Small Business (ICSB) and Nigerian Association of Small and Medium Scale Enterprises (NASME) (Osunde, 2014). In South Africa, the Junior Achievement South Africa (JASA) aims at empowering the youth people who are the seekers and creators of opportunities. The programme also aims to nurture entrepreneurial thinking among youth people (JASA, 2012). One of the objectives of this organization is to train youth individuals for life after school by nurturing the mindfulness of economic issues. 
Changing their mindsets to think entrepreneurially by teaching them entrepreneurial skills, make them understand the business world and improving their intelligence of individual responsibility through practical business knowledge (JASA, 2012). Another agency that the government has developed is National Youth Development Agency (NYDA) which is aimed at ensuring the government and private sector societal development through entrepreneurship by identifying and implementing solutions to the challenges facing the youth in society (Echezona, 2015). Entrepreneur Magazine (2015) argued that this agency is responsible for the provision of grants and soft-loans for both financial and non-financial funding to young entrepreneurs. It also provides grants for mentorship programmes, market linkages, youth co-operative development programmes.

Youth Participation in Entrepreneurship Activities: The United States is well-known for its positive entrepreneurial energy and drive, and its attitude towards entrepreneurship. Young Americans are extra likely to see opportunities compared to the older population in the United States, but they are less likely to be certain that they have the required capabilities for entrepreneurship, and they have a high fear of failure (GEM, 2017). Whereas those who have passed their youth age, in contrast, express much confidence in their capabilities and they are less afraid of failing but they don't see as several opportunities. Entrepreneurial activity in the United States in 2016 revealed extensive involvement across various age groups. Intentions to participate in entrepreneurial activity among non-entrepreneurs declined in the older age groups and among those between 25-34 years old have reached a high of 10\%. This development indicates that the younger population thinks through owning and opening a new business as a sustainable career option in the early stages of adult life (GEM, 2017). It appears that the middle-career population is either constrained by personal obligations, family or is comfortable to employment and is not planning to establish new businesses in the near future. Yet this age group is most probable to start a business. This shows that both startups and organizations among young age group involved in most entrepreneurial activities. However, in the United States, individuals are much involved in entrepreneurial activity when they work on their own rather than for employers. Young people are less likely to feel they have the necessary skill sets to start businesses and more likely to see opportunities to undertake such endeavors.

For the older age groups, the picture is precisely opposite. As individuals grow older, they trust that they have gathered the experience, capabilities and knowledge to start a new venture but they are less likely seeing enough opportunities (GEM, 2017). In South Africa, youth participation in entrepreneurship activities is very worrisome. GEM report 2016 revealed that there is a decline in the involvement of people aged between 2534 years old in entrepreneurial activities, with over 40\% decrease, compared to 2015 and this worrying as this age group tend to be entrepreneurially vibrant. However, the individuals between the age of 25 and 34 years old in 2016 were least entrepreneurially active in South Africa, with even lower rates than those between 18 - 24-year-olds. Out of 65 economies, South Africa is ranked 58th in terms of participation in entrepreneurial activities by 25 to 34 -year-olds. Youth entrepreneurship participation is less effective compared to those of adults group. In 2016, $45-55$ age groups are accounting for more than a quarter $28 \%$ of all early-stage entrepreneurial actions and they are most entrepreneurially active. This growth in entrepreneurship activity might be a cause of older workers who are aware that there are high chances that they can face inadequate prospects on the job market and who are made redundant (GEM, 2017). GEM report (2016) revealed that the percentage of people aged between 18 - 24 years old that are participating in earlystage entrepreneurial activities in South Africa is noticeably lesser than the average for Africa (which is 2.4 higher the South African number for this group) as well as lesser than the average for efficiency-driven economies, which is nearly double South African number which is at $12 \%$. Given the high unemployment rate of South African youth, this is cause for concern.

\section{Barriers that Hinder Youth Entrepreneurship Development}

Access to Credit: Access to credit remains a big challenge in many countries. Sambo (2015) alluded that there is a positive association between the expansion of youth entrepreneurship and access to credit. A study by Mwangi \& Shem (2012) revealed that accessing credit is a huge barrier to the growth and development of small and micro enterprises (SMEs) and, also, to deprived urban and rural families. Access capital for a startup is a huge barrier in one's quest to venture into business. Chimucheka (2012) stated that all businesses require finance to start, operate, sustain and grow. Boates (2013) alluded that most of the business people 
who run small businesses repeatedly discover that they do not qualify for loans and credits due to the fact that they have high debt to equity and no collateral. Turton and Herrington (2012) revealed that 79\% of local entrepreneurs find it difficult for them to access funding, while various believe that funding settings are slowly failing, in terms of the initial public offering, angel investors or bank lending. Further stated that funds for entrepreneurs are not made easily available, and much of the capital is regularly too expensive, which limits the progress of promising businesses. As a result of lack of funding many South African entrepreneurs are discouraged to embark an entrepreneurship journey (Boates, 2013).

Entrepreneurship Education: Around the world the governments have put more effort into interventions that encourage success in entrepreneurship, making an important contribution in entrepreneurship education and training (Valerio, Parton \& Robb, 2014). It is not only happening in developed nations, but it as well happening through the emerging world. According to Njongeri (2015), for example, in Kibera as well as in the rest of Kenya, the alternative forms of education are lacking, and there is inadequate access to secondary schools. Globally, research in entrepreneurship education and training is failing to draw a straight fundamental link associating the improved knowledge with the business successive performance (Valerio, Parton \& Robb, 2014). Nevertheless, compared to their counterparts from other countries, South African youth are still relatively left behind at the pace at which they are setting up their own business projects (GEM, 2017). Fatoki \& Chindoga (2011) alluded that the continuity of this state may not accelerate the pace of youth economic participation, especially considering the high unemployment rate. Sandrock (2011) proposes that matriculates, as well as graduates from universities, should be prepared with entrepreneurial skills to avoid job seekers and promote job creators. Varblane and Mets (2010) stated that learning institutions are failing to equip students/learners with necessary skills that are needed to start, sustain and grow their businesses.

Learners are educated just to pass an exam. Therefore; there is also a necessity in education curriculum at present to include life skills training (Kaburi et al., 2012). Nani (2016) pointed out that learning institutions are still lacking when it comes to entrepreneurship studies, as most institutions focus more on the theoretical aspect of entrepreneurship and less of a practical aspect of entrepreneurship. The author further stated that the education that is taught to students seems to promote job seekers than job creators. Sandrock (2011) stresses out that a group of job creators would be much useful than that of workers. Likewise, Mahadea et al. (2011) trust that discovering the talent of young people by fostering entrepreneurial culture amongst school leaners would be helpful in their well-being. The authors further pointed out that, the education system should be able to advance entrepreneurship knowledge, skills and attitudes in a student. Varblane and Mets (2010) acknowledge that several higher learning institutions in South Africa provide entrepreneurship education. However, they are likely to focus more on the theoretical aspect of entrepreneurship. Nonetheless, the authors suggest that the establishment of business incubators within universities is required in order to successfully deal with the matter of unemployment. Society believes that the white-collar jobs are superior to entrepreneurship, they believe that becoming a nurse, lawyer or a teacher is the best job to pursue (Echezona, 2015).

The authors argue that incubators could assist students with practical exposure by connecting theoretical training with practical training. The author added that such incubators must be able to offer technical assistance and management guidance to youth individuals and potential young entrepreneurs in any issues related to business. Mahadea et al. (2011) argue that on the foundation of the active South African labour market, lots of youth people after completing their secondary education will struggle to find jobs. Thus, the fact that youth should consider starting their jobs as a choice, instead of chasing for paid work in order to fight against this high unemployment rate. The authors suggested that learning systems should be able to influence learner's attitude towards entrepreneurship, and also be able to equip learners with entrepreneurial skills, knowledge. Isaacs, Visser, Friedrich \& Brijal (2007) concur that learning system remains the much important aspect even though there are many components that can inspire people to start a business, such as role models, exposure to entrepreneurship from close families, and so on. The introduction of entrepreneurship studies should be included in the primary school curriculum as it will help to build a solid basis for future entrepreneurial growth to the learners (Udu and Amadi, 2013). Nani (2016) stated that when learners are mentored and taught how to start, run and sustain a business from an early age, the high failure rate of entrepreneurship might be abridged when these graduates arrive in the real business world. 
Parents and Society's Attitude towards Youth Entrepreneurship: The attitude from society is also one of the obstacles that hinder the development of youth entrepreneurship. In Kenya, society's expectations from young people have input in the low development of entrepreneurship among the youth (Kaburi et al., 2012). Parents and older generations have different expectations from the youth and most of them encourage whitecollar jobs because they think is the best way of getting money. Therefore there is little encouragement that is offered to the youth to start their businesses and this overwhelms young people (Kimando, Njogu \& Kihoro, 2012). South African youth also face pressure from parents who believe that after graduation their children have to go look for the jobs to make money (Echezona, 2015). The author further stated that the parent's attitudes make it hard for the youth to create businesses because they put pressure that they have to work in order to fight poverty (Nani, 2016). This perception makes it difficult for youth to start their businesses. Many economies encourage entrepreneurship education and training so as to inspire their citizens to establish encouraging attitude towards entrepreneurship, establish managerial skills for running fruitful businesses, and represent a need to venture into business, inspire new start-ups and other entrepreneurial businesses and identify viable business opportunities (Njoroge \& Gathungu, 2013).

Red Tape and Burdensome Regulations and High Cost of Hiring Workers: The regulations in South Africa have been identified as a critical obstacle facing Small Businesses in South Africa (Echezona, 2015). According to SME Growth Index (2013), small businesses spend much of time dealing with red-tape and that leads to the loss of income. Furthermore, dealing with South African Revenue Services (SARS), labour issues and compliance with Black Economic Empowerment (BEE) is identified by some SMMEs as their red tape. Da Silva (2013) added that the laws that regulating entrepreneurship in South Africa is to some extent inflexible and severe. The author further revealed that registered small and medium businesses in South Africa are more than 1.5 million, which are trusted to contribute $40 \%$ of jobs in the country, but the sad and disappointing part is that these businesses are said to be operating in some kind of unfriendly regulatory environment made by the country's unfavorable entrepreneurship laws (Da Silva, 2013). Entrepreneurship has the potential of inducing job creation in South Africa. However, there is a big challenge when it comes to the high cost of the country's labour system which hampers their willingness to hire workers (Echezona, 2015). Some of the entrepreneurs find it difficult to hire specialist employees that will provide advice and guidance on compliance issues due to the fact that there are more than 45 laws that the businesses need to comply with and have to submit up to 24 returns (Boates, 2013). He further stated that complying with all of these regulations can be a large cost to a business.

Entrepreneurship Culture: The South African business environment and entrepreneurial culture is another challenge that hinders the sustainability of entrepreneurship. This is because the current entrepreneurship environment is very difficult, risky and not conducive for running small businesses and also the failure rate is very high (GEM 2018). The report further specified that the South African environment is not conducive for businesses to grow and in promoting the culture of entrepreneurship, and South Africa was ranked lower than other Sub-Saharan nations when asked about their capabilities as well as their perception of good opportunities.

\section{Research Design and Methodology}

A research design is defined as a plan or strategy for the gathering and analysis of information based on the study research questions (Sekaran and Bougie, 2013). A qualitative research approach was adopted to enable the use of secondary data literature. The researcher chose this research approach because it allows the researcher to provide depth and detailed information. The purpose of this approach was to contextualize the understanding of the barriers that prevent the youth from starting their own businesses. The research methodology was undertaken by systematically reviewing and contextualizing the literature regarding topic under study. Furthermore, there have been many studies undertaken to understand challenges that prevent the youth to participate in entrepreneurship activities. Some studies have also gone to the government support initiative in promoting youth entrepreneurship, hence; the study will have sufficient information to explore and draw conclusions from. Moreover, Gratton \& Jones (2010) claimed that there are always loopholes and gaps in the available literature on specific topics and at times re-examining the literature is often helpful as these gaps may not have been previously uncovered. 
The authors also claimed that using secondary sources can be extremely beneficial in reviewing a current phenomenon that spans a wide geographical range. Moreover, taking into account the historical understanding and debates regarding challenges that prevent the youth to engage in entrepreneurship activities the research approach was adequate as there is vast information regarding the importance of youth entrepreneurship, contribution to the country's economy and challenges hinder the youth to participate in entrepreneurship activities. Therefore, the vast availability of data and the used research approach allowed the study to draw analysis, commentary, opinion pieces and scholarly contributions, sources which are very important allowing the study to draw conclusions from a wide range of sources, hence the reasoning behind the use of this methodological approach. Sources of data included but were not limited to institutional reports from organizations such as the World Bank, journal articles and credible online sources that possess the required data. Therefore, the vast availability of data in a literature context relating to entrepreneurship and the involvement of the youth in South African was the reason this method was selected as a method of preference.

Data Analysis: As stated in the abstract, the research opted to use qualitative data (a thought a systematically reviewing literature), subsequently, data was analyzed using thematic content analysis. The researcher chose thematic content analysis because it allows the researcher to improve and inspect the nuances of people's opinions and trends. Sekaran and Bougie (2013) state that content analysis is the get-together and analysis of textual content and this method of analyzing allows the researcher to analyze a large amount of written information and systematically identify its properties, such as concepts, the presence of certain words and characters. Content analysis is meant to use qualitative methods to recover and analyze data collected from the message content. Basically, this analysis permits the researcher to validate theoretic text to better enrich the understanding of gathered data. Content analysis assists in shedding light on the topic under investigation. Hsieh \& Shannon (2005) suggest that the advantage of utilizing content analysis is that it may fill some gaps which may often be left out through the utilization of other data analysis approaches. Secondary sources allowed the researcher to come up with valid and strong explanations and understandings related to regional integration and their possible benefits for these regions. Seuring \& Gold (2012) maintain that textual analyses are used to analyze literature work for the intention of explaining their originality and validity. This among others covers reading and reviewing and from the discussion of applicable data retrieved. Hence, the aim of textual criticism is to define the message, purpose and structure of the text.

\section{Theoretical Framework}

The Process Driven Theory Developed by Bandura in1986: This theory articulates that action is reliant upon the perception of an individual that can lead to the intended action. This theory emphasized that the external environment affects thought, which forms an intention and shapes attitude, which is solid enough leads one to action (Fatoki and Chindoga, 2011). Hence this study examines the external influence that prevents the youth in participating or engaging in entrepreneurship activities.

The Need for Achievement Theory (NAT): This theory is a psychological theory suggested by David McClelland in 1965. The theory points out a strong relationship between entrepreneurial activities and the need for achieving economic expansion (Echezona, 2015). Echezona (2015) further stated that supporters of the theory explain that in a society where the need for entrepreneurship is high there would be a fairly greater quantity of entrepreneurial activities. Meaning the support from society has an influence on the adoption of entrepreneurship activities. The root of the theory is that when learners or students are adequately encouraged through entrepreneurship education to become job creators, there is a greater chance for them to start-up their businesses after school (Echezona, 2015). This theory is relevant to this study because it stresses that when learners or students are motivated to engage in entrepreneurship activities that will inspire them to start their own businesses, which of support to this study because it is found that one of the challenges faced by the youth is lack of support from the society and lack of entrepreneurship education.

Schumpeter Theory of Innovation: The theory regards the challenges of unemployment as the absence in new businesses that are being created when new businesses are established employment is created through the formation of those businesses (Garofoli, 1994). Echezona (2015) in Jovanovic (1982) stated that high unemployment rate is often related with poor entrepreneurial activities, which means where people do not 
have the pleasure to acquire innovation, business skills and knowledge to start their own businesses, the unemployment rate remains very high. The suggestion of Schumpeter is that unemployment is likely to be precisely high because most people are not well prepared with entrepreneurial talents and human capital necessary to start and sustain new business ventures (Echezona, 2015).

\section{Findings and Discussion}

The findings revealed that there are various barriers that prevent the youth to engage in entrepreneurship activities. Barriers that have been found as have the major effect in preventing the youth from participating in entrepreneurship are entrepreneurship education, lack of access to credit, parents and society's attitude towards entrepreneurship, red tape and burdensome regulations, high cost of hiring workers and entrepreneurship culture. The findings revealed that the education that is given to the youth does not equip them with entrepreneurial skills and it promotes white-collar jobs rather than the self-employment. It is also found that parents and society have the belief that the white-collar jobs are superior to entrepreneurship which gives the youth the mindset that in order for them to survive and become successful they have to work for other people. In Zambia, Masanta (2017) found that there was great potential for the youth to participate in entrepreneurial activities, the study conducted by Gwija, Eresia-Eke \& Iwu (2014) revealed that South African youth faces wide range of challenges which are: lack of start-up and development capital, absence of government support, red tape, labour laws and harsh business regulation and inappropriate entrepreneurship education.

Another study conducted by Ceptureanu and Ceptureanu (2015) revealed that youth entrepreneurs parents and social support, financial support, lack of information and skills, socio-cultural attitude, the low value of entrepreneurship education and difficulties to access finance are found to be the challenges that are preventing the youth in starting their own businesses. The environment also should be conducive and impose opportunities for businesses. However, efforts to ensure youth participation in the country were compounded by a lack of policy direction, credit facilities and the entrenchment of business guidance services. Similarly, in Nigeria, Okeke (2014) revealed that as a result of many issues preventing and affecting its growth and development, leadership and entrepreneurial ability tend to be lacking in Nigeria, the author further expounded that economic and social progress in Nigeria still falls far short to influence the wellbeing of the average Nigerian given that half of Nigeria's population earn less than one dollar a day and regrettably, the government has not prioritized policies that would boost youth participation in the country entrepreneurial sector and this is unfortunate as youth entrepreneurship has the ability to reduce the socioeconomic challenges being experienced by the country.

One may, therefore, conclude that challenges facing the participation of youth in entrepreneurial activities are not only affecting South Africa but are a continental problem which seemingly has governments in the continent with little or no policy as to how to respond to this growing crisis. The findings revealed that the South African environment is not conducive enough for young people to participate in entrepreneurship activities. The environment is not conducive for businesses to grow and in promoting the culture of entrepreneurship. It was also found that South Africa is still lacking when it comes to good opportunities and capabilities when it is compared to other countries. It was found that even the laws in South Africa that regulating entrepreneurship is inflexible and severe. Businesses in South Africa are operating in some kind of unfriendly governing environment made by the country's unfavorable entrepreneurship laws, which makes it tough for businesses to continue operating and grow in this kind of the environment (GEM, 2018). The study conducted by Boates (2013) also revealed that financial institutions want the collateral in order to finance businesses and for those with no collateral it is difficult to get finance. The study further revealed that access to finance is a big challenge that hinders the establishment of businesses.

\section{Conclusion and Recommendations}

The educational curriculum should be improved in terms of entrepreneurship education, the entrepreneurship education should start at the primary level so that the learners will grow up with entrepreneurship mindset and entrepreneurship education must be offered to all students. Learning institutions should establish incubators that will help in terms of the practice entrepreneurship where 
learners will put entrepreneurship theory that they obtained into action. Society and parents should support and promote entrepreneurship to their children, teach them the importance of being your own boss instead of promoting white-collar jobs. This will nurture and develop the entrepreneurship mindsets. Finance is important in the operation of all businesses. Therefore, finance must be made available to start-up businesses. If you have a brilliant idea the financial institutions must grant you finance without asking things like collateral. Policymakers should establish laws and regulations that will favour businesses, laws that will allow businesses to grow and encourage youth to start businesses. Entrepreneurship is an important factor for reducing poverty, creating job opportunities and the economic growth of every country. Therefore, looking to the challenges that hinder the development of entrepreneurship is very important especially to this high unemployment rate that South Africa faces.

Equipping the youth to engage in entrepreneurship activities could help to reduce the high unemployment rate that the South African youth are facing, it will also help to improve the South African economy. Society needs to be taught about the importance of entrepreneurship so that they will be aware what the role it plays to the economy and that will encourage them to support their children and encourage them to start their businesses instead of encouraging job seeking. Furthermore, apart from the above, there is a great need for the creation of a coalition of private and government entities to ensure that policies meant to entice the youth into participating in entrepreneurship are streamlined and speak to each other. Moreover, from a government's point of view, there is great need of policy consultation with the youth to better understand what the real barriers are and how government can address such as collective through collaboration and robust stakeholder engagement. Furthermore, one notes that there are institutions which have been set up by governments to ensure the business support for young and upcoming entrepreneurs, however, young people looking into venturing into entrepreneurship have cited the lack of finance and advice as major factors hindering their development and entrance in this sector, which then means there is greater need for government to strengthen the overall stability and governance of these institutions.

\section{References}

Boates, C. (2013). Too Many Obstacles Still Hindering SA's Entrepreneurial Growth: The EOY team posted on June 4, 2013.

Ceptureanu, S. I. \& Ceptureanu, E. G. (2015). Challenges and barriers of European young entrepreneurs. Management research and practice, 7(3), 34-58.

Chiloane-Tsoka, G. E. \& Mmako, N. M. (2014). Effects of migration and immigration on SMMEs: the case study of Diepsloot informal settlement, South Africa. Problems and Perspectives in Management, 12(4), 377383.

Chimucheka, T. (2012). The impact of entrepreneurship education on the performance of Small, Micro and Medium Enterprises in the Buffalo city metropolitan municipality. Published (masters.), University of Fort Hare.

Da Silva, M. C. (2013). South Africa Business Network.

Echezona, M. (2015). Entrepreneurship education as a strategy for the promotion of entrepreneurship culture and poverty reduction among university students. Published (Masters.), University of Fort Hare.

Egwu, I. L. (2014). Entrepreneurship development in Nigeria: A review.

Entrepreneur Magazine. (2015).

Fatoki, O. \& Chindoga, L. (2011). An Investigation into the Obstacles to Youth Entrepreneurship in South Africa. International Business Research, 4(2), 161-169.

Garofoli, G. (1994). New Firm Formation and Regional Development: The Italian Case, Reg. Studies, 28, 381393.

Global Entrepreneurship Monitor report. (2016). South African report. Is South Africa heading for an economic meltdown?

Global Entrepreneurship Monitor report. (2017). National Entrepreneurial Assessment for the United States of America.

Global Entrepreneurship Monitor report. (2018).

Global Entrepreneurship Monitor. (2017). South African report. Can small businesses survive in South Africa? Gordon-Davis, L. \& Cumberlege, P. (2007). Legal Issues for Entrepreneurs. Cape Town: Juta. 
Gratton. \& Jones. (2010). Research methods for sports studies. Routledge. Abingdon.

Gwija, S. A., Eresia-Eke, C. \& Iwu, C. G. (2014). Challenges and prospects of youth entrepreneurship in a designated community in the Western Cape, South Africa. Journal of economics and behavioral studies, 6(1), 10-20.

Hsieh, H. F. \& Shannon, S. E. (2005). Three approaches to qualitative content analysis. Qualitative Health Research, 15(9), 1277-1288.

Isaacs, E., Visser, K., Friedrich, C. \& Brijal, P. (2007). Entrepreneurship education and training at the Further Education and Training (FET) level in South Africa. South African Journal of Education, 27(4), 613629.

James, W. (2012). Youth entrepreneurship is the key to future growth.

Junior Achievement South Africa. (2012).

Kaburi, S. N., Mobegi, V. O., Kombo, A., Omari, A. \& Sewe, T. (2012). Entrepreneurship Challenges in Developing Economies: a case of Kenyan Economy. International Journal of Arts and Commerce, 1(4), 264-274.

Khin, S. \& Khan, D. (2017). Perspectives of start-up entrepreneurs on challenges, support services and entrepreneurial ecosystem.

Kimando, L. N., Njogu, G. W. \& Kihoro, J. M. (2012). Factors Affecting the Success of Youth Enterprise Development Funded Projects in Kenya; A Survey of Kigumo District Muranga County. International Journal of Business and Commerce, 1(10), 61-81.

Mahadea, D., Ramroop, S. \& Zewohir, T. (2011). Assessing Entrepreneurship Perceptions of High School Learners in Pietermaritzburg, KwaZulu Natal, 14(1), 66-79.

Masanta, F. (2017, January 01). Future at risk, Retrieved from: https://www.dandc.eu/en/article/youthunemployment-remains-key-challenge-zambia.

Mazwai, E. T. (2010). The effectiveness of local business service centers in small business development: A case study of Gauteng province South Africa, Pretoria University of Pretoria.

Moraa new hope foundation. (2015). Challenges facing Kenyan youths.

Musengi-Ajulu, S. (2010). What do we know about the entrepreneurial intentions of the youth in South Africa? Preliminary results of a pilot study.

Mwangi, I. W. \& Shem, A. O. (2012). Social capital and access to credit in Kenya, American Journal of Social and Management Sciences.

Nafukho, F. M. \& Muyia, M. A. H. (2010). Entrepreneurship \& Socioeconomic development in Africa: A reality or myth? Journal of European Industrial Training, 34(2), 96-109.

Nani, G. V. (2016). Entrepreneurial education in the school curriculum: in search of positioning in Zimbabwe. Problems and Perspectives in Management, 14(3), 85-90.

National Youth Development Agency Report. (2011). National Youth Development Agency, Annual Report.

Njongeri, W. (2015). Influence of entrepreneurship education in developing entrepreneurs in Kenya: The case study of Jomo. Kenyatta University of agriculture and technology.

Njoroge, C. W. \& Gathungu, J. M. (2013). The effect of entrepreneurial education and training on development of small and medium size enterprises in githunguri district - Kenya. International Journal of Education and Research, 1(8).

Okeke, M. I. (2014). Challenges facing entrepreneurs in Nigeria. Singaporean Journal of Business, Economics and Management Studies, 51(1812), 1-17.

Olawale, F. \& Garwe, D. (2010). Obstacles to the growth of new SMEs in South Africa: A Principal component analysis approach. African Journal of Business Management, 4(5), 729-738.

Osunde, C. (2014). Entrepreneurship in developing countries: the Nigerian experience centers.

Sagwe, J., Gicharu, S. \& Mahea, T. (2011). A Study on Youth and Women Entrepreneurs' Preparedness in Kenya: A Case Study of the Kenya Youth Enterprise Development Fund.

Sambo, W. (2016). Factors affecting youth entrepreneurship development within Kibera, Kenya: the perspective of entrepreneurship education. Problems and Perspectives in Management, 14(2-2), 331338.

Sandrock, J. (2011). National Report into the state of entrepreneurship. Economic Growth = Growing Entrepreneurship.

Sekaran, U. \& Bougie, R. (2013). Research Method for Business: A Skill Building Approach. 6th ed. United Kingdom: Wiley 
Seuring, S. \& Gold, S. (2012). Conducting content-analysis based literature reviews in supply chain management.

SME Growth Index. (2013). Effect of Red Tape on small firms in South Africa.

Statistics South Africa. (2019). Quarterly labour force survey.

Turton, N. \& Herrington, M. (2012). Global Entrepreneurship Monitor: 2012 South Africa Report. Cape Town: University of Cape Town Graduate School of Business.

Udu, C. S. \& Amadi, U. P. N. (2013). Integrating Basic Entrepreneurship Studies into Primary Education Curriculum: Platform for Sustainable National Development. Academic Journal of Interdisciplinary Studies, 2(5).

Valerio, A., Parton, B. \& Robb, A. (2014). Entrepreneurship Education and Training Programs around the World: Dimensions for Success. World Bank, Washington DC.

Varblane, U. \& Mets, T. (2010). Entrepreneurship education in the higher education institution of postcommunist European countries. Journal of enterprising communities: people and place in the global economy, 4(3), 204-219. 